\title{
PENGARUH MOTIVASI DAN DISIPLIN KERJA TERHADAP KINERJA PEGAWAI PADA DINAS PERTANIAN KABUPATEN SUPIORI
}

\author{
Johanes Eliezer Ayer \\ Lyndon R.J. Pangemanan \\ Yolanda P.I. Rori
}

\begin{abstract}
This study aims to identify and analyze whether there is influence motivation and discipline the performance of employees in the District Agriculture Office Supiori. This research is classified as causal research associative quantitative approach to the instrument in the form of a questionnaire. The population in this study were all employees of the District Agriculture Office Supiori as many as 80 people. The sampling technique by means of saturated or census sampling technique. The sample in this research is to take the population, or as many as 80 samples. The data used in this study are primary data obtained through questionnaires and secondary data related agencies and journals to support this research. Test the validity of the instrument using bivariate Correclation formula, while the reliability test using Cronbach Alpha. Measuring instrument proved valid and reliable for research instruments. Multiple regression analysis used to test hypotheses of this study. The results showed that: motivation (X1) positive and significant impact on employee performance Supiori of Agriculture Office ( $\beta$ ) 0.413 with significantly 0,01. Labor discipline (X2) positive and significant impact on employee performance Supiori of Agriculture Office ( $\beta$ ) 0.741 with significantly by 0,00. And based on the test results both independent variables were tested individually dominant in influencing the performance of employees in Supiori District Agriculture Office is working discipline (with a coefficient of 0.489). It can be concluded that in this study the discipline of work (X2) partially are factors that significantly affect performance $(Y)$.
\end{abstract}

Keywords: motivation, labor discipline, performance, Agriculture Office at Supiori Regency, Papua

\begin{abstract}
ABSTRAK
Penelitian ini bertujuan untuk mengetahui dan menganalisis apakah terdapat pengaruh motivasi dan disiplin kerja terhadap kinerja pegawai di Dinas Pertanian Kabupaten Supiori. Penelitian ini dikategorikan sebagai penelitian kausal asosiatif pendekatan kuantitatif dengan instrumen berupa kuesioner. Populasi dalam penelitian ini adalah seluruh pegawai Dinas Pertanian Kabupaten Supiori sebanyak 80 orang. Teknik pengambilan sampel dengan cara teknik sampling jenuh atau sensus. Sampel dalam penelitian ini adalah dengan mengambil populasi atau sebanyak 80 sampel. Data yang digunakan dalam penelitian ini adalah data primer yang diperoleh melalui Kuesioner dan data sekunder yang diperoleh instansi dan jurnal terkait untuk mendukung penelitian ini. Uji validitas instrumen menggunakan rumus Correclation Bivariate, sedangkan uji reliabilitas menggunakan Cronbach Alpha. Alat ukur terbukti valid dan reliabel untuk instrumen penelitian. Analisis regresi berganda digunakan untuk uji hipotesis penelitian ini. Hasil penelitian menunjukan bahwa: Motivasi (X1) berpengaruh positif dan signifikan terhadap kinerja pegawai Dinas Pertanian Kabupaten Supiori sebesar ( $\beta$ ) 0,413 dengan signikansi sebesar 0,01. Disiplin kerja (X2) berpengaruh positif dan signifikan terhadap kinerja pegawai Dinas Pertanian Kabupaten Supiori sebesar $(\beta)$ 0,741 dengan signifikansi sebesar 0.00. Dan berdasarkan hasil uji kedua variabel independent yang diuji secara individual yang paling dominan dalam mempengaruhi kinerja pegawai di Dinas Pertanian Kabupaten Supiori adalah disiplin kerja (dengan koefisien 0,489). Maka dapat disimpulkan bahwa pada penelitian ini disiplin kerja (X2) secara parsial merupakan faktor yang berpengaruh nyata terhadap Kinerja (Y).
\end{abstract}

Kata Kunci: motivasi, disiplin kerja, kinerja pegawai, Dinas Pertanian, Kabupaten Supiori, Provinsi Papua 


\section{PENDAHULUAN}

\section{Latar Belakang}

Sumber daya manusia merupakan penggerak utama jalannya kegiatan sebuah organisasi, maju mundurnya suatu organisasi ditentukan oleh keberadaan sumber daya manusianya. Sehingga sumber daya manusia atau pegawai dalam sebuah organisasi menjadi perhatian penting dalam rangka usaha mencapai keberhasilan organisasi.

Keberhasilan suatu organisasi dalam mencapai tujuan organisasi ditentukan oleh kinerja pegawai. Kemampuan pegawai mengerjakan pekerjaan yang menjadi tanggung jawabnya menjadi tolok ukur pencapaian tujuan organisasi. Apabila suatu organisasi mampu mencapai tujuan yang telah ditetapkan, maka dapat dikatakan bahwa organisasi tersebut efektif. Seiring dengan berkembangnya waktu, semua organisasi dituntut untuk dapat bersaing memberikan pelayanan yang terbaik, termasuk organisasi pemerintah.

Pelayanan yang terbaik, tidak dapat dilepaskan dari peran setiap pegawainya. Seorang pegawai harus bisa bekerja secara optimal dimana hal ini dapat dilihat atau diukur melalui kinerja pegawai tersebut. Menurut Mangkunegara (2011), berpendapat bahwa kinerja adalah hasil kerja secara kualitas dan kuantitas yang dicapai oleh seorang pegawai dalam melaksanakan tugasnya sesuai dengan tanggung jawab yang diberikan kepadanya.

Kinerja yang baik adalah kinerja yang optimal, yaitu kinerja yang sesuai standar organisasi dan mendukung tercapainya tujuan organisasi. Peningkatan kinerja pegawai akan membawa kemajuan bagi instansi (organisasi) untuk dapat bertahan dalam suatu persaingan yang tidak stabil. Kinerja pegawai dipengaruhi oleh beberapa faktor baik yang berhubungan dengan tenaga kerja itu sendiri maupun yang berhubungan dengan lingkungan perusahaan atau organisasi. Wexley dan Yukl (2005), mengidentifikasi faktor-faktor yang mempengaruhi kinerja antara lain adalah motivasi dan disiplin kerja.

Dinas Pertanian di Kabupaten Supiori merupakan unsur pelaksana Otonomi daerah, yang mempunyai tugas menyelenggarakan kewenangan desentralisasi dan dekonsentrasi di bidang pertanian dan juga sebagai suatu organisasi pemerintah yang mengemban tugas meningkatkan kesejahteraan masyarakat melalui peningkatan ketersediaan kebutuhan masyarakat umum, yaitu ketersediaan hasil-hasil pertanian yang menjadi kebutuhan pokok manusia lebih khusus kebutuhan masyarakat yang ada disekitar atau yang masuk dalam lingkup pelayanan dinas pertanian ini, sehingga sesuai dengan Keputusan Menteri Negara Pendayagunaan Aparatur Negara (Meneg PAN) Nomor 63/KEP/M.PAN/7/2003, memberikan pengertian pelayanan publik yaitu segala kegiatan pelayanan yang dilaksanakan oleh penyelenggara pelayanan publik sebagai upaya pemenuhan kebutuhan penerima pelayanan maupun pelaksanaan ketentuan peraturan perundang-undangan.

Pelayanan yang diberikan oleh dinas pertanian sangat dipengaruhi oleh keberadaan dari sumber daya manusia atau pegawaipegawai yang ada didalam dinas tersebut. Pegawai Dinas Pertanian Kabupaten Supiori saat ini dipimpin oleh Kepala Dinas, didampingi Sekretaris Dinas, Kepala Bidang, Kasubbag, Kasie serta staff-staff yang berjumlah 80 orang.

Dengan jumlah pegawai yang memadai tersebut kemudian di bagi ke dalam beberapa bagian pekerjaan sesuai dengan struktur organisasi. Pembagian pekerjaan pegawai pada Dinas Pertanian Kabupaten Supiori dapat dilihat pada tabel berikut:

Berdasarkan Tabel 1 dapat dilihat bahwa jumlah bagian terbesar berada pada bagian staff sebesar 59 orang $(73,75 \%)$ diasumsikan bahwa bagian yang mempunyai tugas dan pelaksanaan pelayanan yang sibuk sehingga membutuhkan pegawai dalam jumlah yang besar. Sementara bagian lain membutuhkan pegawai yang lebih kecil. Pembagian jumlah pegawai tersebut proposional berdasarkan pelaksanaan pelayanan pekerjaan.

Menurut Mc Clelland dalam Mangkunegara, (2011) seorang pegawai dikatakan memiliki motivasi kerja yang tinggi apabila, didalam dirinya memiliki: (1) need of achievement (kebutuhan berprestasi) yaitu kemampuan pegawai untuk mencapai hubungan pada standar yang ditetapkan instansi, (2) need 
of affiliation (kebutuhan afiliasi) yaitu keinginan pegawai untuk saling bersahabat dan mengenal lebih jauh teman kerja dalam sebuah organisasi pemerintahan, dan (3) need of power (kebutuhan kekuasaan) yaitu kebutuhan yang membuat pegawai berperilaku wajar dalam melaksanakan tugasnya serta keinginan untuk menguasai sesuatu, akan tetapi dalam hal ini instansi belum maksimal memberikan dorongan atau motivasi pada para pegawai pada dinas pertanian kabupaten supiori, kurangnya perhatian dari atasan terhadap bawahan, hal ini diduga penyebab dari pegawai tidak memiliki keinginan ataupun dorongan untuk mencapai kinerja yang melebihi standar yang telah ditetapkan.

Sementara disiplin kerja adalah suatu sikap, perilaku yang dilakukan secara sukarela dan penuh kesadaran serta keadaan untuk mengikuti peraturan yang telah ditetapkan instansi baik tertulis maupun tidak tertulis (Nitisemito, 2002). Tanpa disiplin pegawai yang baik, sulit bagi organisasi perusahaan atau instansi mencapai hasil yang optimal. Seorang Pegawai yang mempunyai tingkat kedisiplinan yang tinggi akan tetap bekerja dengan baik walaupun tanpa diawasi oleh atasan, tidak akan mencuri waktu kerja untuk melakukan hal-hal lain yang tidak ada kaitannya dengan pekerjaan, akan mentaati peraturan yang ada dalam lingkungan kerja dengan kesadaran yang tinggi tanpa ada rasa paksaan.

Disiplin kerja dapat mempengaruhi kinerja pegawai, pernyataan ini diperkuat dengan adanya pendapat dari Malayu S.P Hasibuan (2000) "Semakin baik disiplin kerja seseorang, maka semakin tinggi hasil prestasi kerja (kinerja) yang akan dicapai”. Disiplin kerja pegawai dinas pertanian supiori bisa dilihat dari tingkat kehadiran dan ketepatan waktu datang ke kantor. Hal ini bisa dilihat dari tingkat absensi yang dicapai. Metode absensi di kantor dinas pertanian supiori menggunakan sidik jari (finger), sehingga bisa tepat dan akurat dalam hal menilai kedisplinan para pegawai.

Berdasarkan hasil observasi yang dilakukan pada bulan Agustus-September 2016 diketahui bahwa menurunnya kinerja pegawai pada Dinas Pertanian Kabupaten Supiori disebabkan oleh kedisiplinan kerja pegawai. Kedisiplinan kerja pegawai yang menurun paling mudah terlihat dari ketepatan waktu datang ke kantor, dimana dari total pegawai yang ada, ratarata setiap harinya ada $6 \%-7 \%$ pegawai yang datang terlambat selain dilihat dari keterlambatan dalam waktu datang ke kantor, menurunnya kedisiplinan kerja pegawai juga dapat dilihat tingkat kehadiran pegawai yg datang ke kantor.

Berikut ini tingkat kehadiran para pegawai di lingkungan Dinas Pertanian Kabupaten Supiori: Berdasarkan Tabel 2 diatas dapat diketahui bahwa tingkat kehadiran pegawai di Dinas Pertanian Kabupaten Supiori selama 1 tahun terakhir terlihat bagaimana ketidakdisiplinan pegawai terhadap absensi kantor. Mudiartha, dkk (2001) menyatakan ratarata absensi 2-3\% per bulan masih bisa dinyatakan baik, dan absensi lebih dari 3\% menggambarkan kondisi disiplin kerja yang tidak baik dalam organisasi. Hasil yang menunjukkan tingkat absensi yakni di atas 3\% ini menunjukkan bahwa ada suatu hal yang menjadi indikasi masalah yang terjadi di dalam proses operasional kinerja pegawai pada Dinas Pertanian Kabupaten Supiori. Secara rinci, Ketidakdisiplinan pegawai terjadi karena terdapat indikasi masih lemahnya sistem yang mengatur tentang kedisiplinan pegawai. Sistem tersebut antara lain pengawasan dari pemimpin terhadap kedisiplinan pegawai serta sanksi yang akan diterima oleh pegawai apabila mereka tidak disiplin. Pemimpin dinas pertanian supiori dalam hal ini adalah Kepala dinas dinilai kurang tegas dalam memberi sanksi terhadap pegawai yang tidak disiplin.

Menurunnya kinerja pegawai juga disebabkan oleh rendahnya dorongan dalam diri sendiri untuk bekerja sama, bekerja efektif dalam mencapai tujuan. Kurangnya perhatian atasan kepada bawahan juga menyebabkan motivasi pegawai di Dinas Pertanian Supiori rendah. Pegawai lebih suka melimpahkan tugas yang sudah menjadi tanggung jawab mereka kepada pegawai kontrak sehingga keinginan untuk memotivasi diri sendiri belum maksimal, dan juga atasan kurang intens dalam memberikan motivasi kepada pegawai bawahannya, sehingga berdampak rendahnya semangat kerja pegawai, karena merasa kurang diperhatikan dan mengakibatkan kinerja pegawai menjadi tidak optimal.

$$
\text { Faktor lain yang menyebabkan }
$$
menurunnya kinerja pegawai dinas pertanian supiori adalah lingkungan kerja fisik yang kurang 
mendukung produktivitas kerja, yaitu ruangan kerja yang gelap, saling terbuka dan berdempetan sehingga pegawai merasa sempit. Beberapa pegawai juga menyebutkan menurunnya kinerja disebabkan adanya beban kerja yang tinggi dan minimnya penghargaan yang diberikan atas kinerja yang dicapai oleh para pegawai. Tingkat disiplin kerja pegawai dan motivasi pegawai akan sangat mempengaruhi kinerja pegawai dan berpengaruh terhadap produktivitas sebuah instansi pemerintahan. Instansi tidak dapat berjalan dengan baik bila pengelolaan pegawai dalam kedisplinan dan motivasi terhadap pegawai tidak dikelola dengan sebaik-baiknya. Kondisi di atas menimbulkan permasalahan dalam pencapaian kinerja Dinas Pertanian Kabupaten Supiori. Pencapaian kinerja yang belum optimal diduga dikarenakan kurangnya disiplin kerja pegawai dan rendahnya motivasi. Berdasarkan latar belakang diatas, maka penelitian ini diberi judul "Pengaruh Motivasi dan Disiplin Kerja terhadap Kinerja Pegawai pada Dinas Pertanian Kabupaten Supiori”.

Tabel 1. Pengelompokan Pegawai Berdasarkan Bagian Pekerjaan Dinas Pertanian

\begin{tabular}{lll}
\hline Bagian Pekerjaan & Jumlah & Persentase \\
\hline Kepala Dinas & 1 & 1,25 \\
Sekretaris Dinas & 1 & 1,25 \\
Kepala Sub Bagian & 3 & 3,75 \\
Kepala Bidang & 4 & 5 \\
Kepala Seksi & 12 & 15 \\
Staf & 59 & 73,75 \\
\hline Jumlah & 80 & $100 \%$ \\
\hline
\end{tabular}

Sumber: Kantor Dinas Pertanian Kabupaten Supiori, 2016

Tabel 2. Dinas Pertanian Kabupaten Supiori Tingkat Absensi Pegawai Tahun 2015-2016

\begin{tabular}{lllllllll}
\hline No. & Bulan & Tahun & $\begin{array}{l}\text { Total } \\
\text { Pegawai }\end{array}$ & $\begin{array}{l}\text { Total } \\
\text { Hari } \\
\text { Kerja }\end{array}$ & $\begin{array}{l}\text { Total KPS } \\
\text { (Orang ) }\end{array}$ & $\begin{array}{l}\text { Absensi } \\
\text { Pegawai } \\
\text { (Orang ) }\end{array}$ & $\begin{array}{l}\text { Total } \\
\text { Kehadiran } \\
\text { (Orang) }\end{array}$ & $\begin{array}{l}\text { Persentase } \\
\text { Kehadiran } \\
\text { Pegawai (\%) }\end{array}$ \\
\hline 1 & September & 2015 & 80 & 21 & 1680 & 75 & 1605 & $4,46 \%$ \\
2 & Oktober & 2015 & 80 & 21 & 1680 & 64 & 1616 & $3,81 \%$ \\
3 & November & 2015 & 80 & 20 & 1600 & 75 & 1525 & $4,68 \%$ \\
4 & Desember & 2015 & 80 & 20 & 1600 & 68 & 1532 & $4,25 \%$ \\
5 & Januari & 2016 & 80 & 21 & 1680 & 72 & 1608 & $4,28 \%$ \\
6 & Februari & 2016 & 80 & 21 & 1680 & 70 & 1610 & $4,17 \%$ \\
7 & Maret & 2016 & 80 & 21 & 1680 & 65 & 1615 & $3,86 \%$ \\
8 & April & 2016 & 80 & 22 & 1760 & 79 & 1681 & $4,48 \%$ \\
9 & Mei & 2016 & 80 & 22 & 1760 & 80 & 1680 & $4,54 \%$ \\
10 & Juni & 2016 & 80 & 22 & 1760 & 76 & 1684 & $4,32 \%$ \\
11 & Juli & 2016 & 80 & 22 & 1760 & 74 & 1686 & $4,20 \%$ \\
12 & Agustus & 2016 & 80 & 20 & 1600 & 69 & 1531 & $4,31 \%$ \\
13 & September & 2016 & 80 & 21 & 1680 & 76 & 1604 & $4,52 \%$ \\
& & & & & & Rata-rata : & $\mathbf{4 , 2 9 \%}$ \\
\hline
\end{tabular}

Sumber : Bagian Umum Dinas Pertanian kabupaten Supiori , 2016 (Diolah)

\section{Rumusan Masalah}

Berdasarkan latar belakang masalah yang telah dikemukakan di atas maka yang menjadi permasalahan adalah:

1) Apakah motivasi berpengaruh terhadap kinerja pegawai Dinas Pertanian Kabupaten Supiori ?
2) Apakah disiplin kerja berpengaruh terhadap kinerja pegawai Dinas Pertanian Kabupaten Supiori?

\section{Tujuan Penelitian}

Berdasarkan latar belakang penelitian dan permasalahan, maka tujuan yang ingin dicapai dalam penelitian ini adalah: 
1) Menguji dan menganalisis pengaruh motivasi terhadap kinerja pegawai Dinas Pertanian Kabupaten Supiori.

2) Menguji dan menganalisis pengaruh disiplin kerja terhadap kinerja pegawai Dinas Pertanian Kabupaten Supiori.

\section{Manfaat Penelitian}

1) Bagi peneliti dapat melatih cara berpikir serta menganalisis data dan penelitian ini merupakan salah satu syarat untuk memperoleh gelar sarjana di Fakultas Pertanian Universitas Sam ratulangi Manado.

2) Bagi pemerintah dalam menilai kinerja pada Dinas Pertanian Kabupaten Supiori. Pengambilan keputusan dan pelaksanaan perubahan-perubahan ke arah perbaikan, dalam mencapai efisiensi dan efektifitas pelaksanaan tugas pokok dan fungsi, serta ketaatan terhadap peraturan perundang-undangan yang berlaku dalam rangka pelaksanaan misi instansi serta mampu memberikan pelayanan terbaik bagi masyarakat.

3) Bagi peneliti lain, dapat dijadikan referensi kajian dalam bidang penelitian serupa.

\section{METODE PENELITIAN}

\section{Tempat dan Waktu Penelitian}

Penelitian ini dilakukan di Dinas Pertanian Kabupaten Supiori yang beralamat Jalan. Sorendiweri-Korido Km 8-9 Wakre. Waktu penelitian ini dilakukan selama 2 bulan, yaitu bulan Agustus-September 2016 sampai dengan selesai.

\section{Populasi}

\section{Populasi dan Sampel}

Populasi dalam penelitian ini adalah seluruh pegawai di Dinas Pertanian Kabupaten Supiori yang berjumlah 80 orang.

\section{Sampel}

Teknik pengambilan sampel untuk menentukan sampel yang akan digunakan dalam penelitian ini menggunakan teknik sampling jenuh atau sensus. Dimana semua anggota populasi di jadikan sampel (jumlah populasi diambil semua karena pertimbangan semua sampel dapat dijangkau dan dijadikan responden Penelitian). Sugiyono (2011)

\section{Jenis dan Sumber Data}

\section{Data Primer}

Data primer yaitu data yang diperoleh secara langsung dari responden di lokasi penelitian sesuai dengan masalah yang diteliti. Data Primer diperoleh dengan membagikan kuesioner yang berisi beberapa pernyataan kepada responden, selanjutnya responden mengisi pernyataan-pernyataan yang terdapat dalam kuesioner. Kuesioner yang telah diisi oleh responden kemudian dikumpulkan kepada peneliti.

\section{Data Sekunder}

Data sekunder adalah data primer yang telah diolah lebih lanjut. Data ini diperoleh melalui studi dokumentasi dan jurnal penelitian yang dapat menjadi referensi bagi penelitian ini.

\section{Metode Pengumpulan Data}

Metode pengumpulan data yang digunakan adalah:

\section{Kuesioner}

Kuesioner merupakan teknik pengumpulan data yang dilakukan dengan cara memberi seperangkat pernyataan tertulis kepada responden untuk dijawabnya. Dalam hal ini responden hanya menjawab dengan cara memberi tanda tertentu pada alternatif jawaban yang disediakan. Selanjutnya responden mengisi pernyataan-pernyataan yang terdapat dalam kuesioner, pernyataan menyangkut variabel motivasi, disiplin kerja, dan kinerja pegawai. Kuesioner yang telah diisi oleh responden kemudian dikumpulkan kepada peneliti.

\section{Skala Pengukuran Variabel dan Analisis Indeks Jawaban Responden}

\section{Skala Pengukuran Variabel}

Penelitian ini menggunakan skala pengukuran, yaitu likert scale untuk mengukur persepsi dari responden yang telah dikumpulkan. Sugiyono, 2004 (dalam Fardiani 2013). Dengan Skala Likert maka variabel yang akan diukur dijabarkan menjadi indikator variabel.

Pernyataan-pernyataan dalam kuesioner dibuat dengan menggunakan skala 1-5 untuk mewakili pendapat para responden. 


\section{Analisis Indeks Jawaban Responden}

Analisis indeks jawaban responden dilakukan untuk mendapatkan gambaran deskriptif penelitian yang dilakukan terhadap tiap indikator dari masing-masing variabel. Analisis ini berguna untuk mengetahui respon responden terhadap setiap pertanyaan atau pernyataan yang diajukan.

\section{Konsepsi Pengukuran Variabel Penelitian}

1. Variabel Dependen

Kinerja adalah hasil kerja secara kualitas dan kuantitas yang dicapai oleh seorang pegawai dalam melaksanakan tugasnya sesuai dengan tanggung jawab yang diberikan kepadanya (Mangkunegara 2009). Dalam penelitian ini peneliti menetapkan kinerja pegawai negeri sipil (Y) sebagai variabel terikat atau dependen. Kinerja pegawai negeri sipil dalam penelitian ini merupakan hasil kerja pegawai negeri sipil di dinas Pertanian supiori selama periode 2016. Indikator yang digunakan dalam penelitian ini untuk mengukur kinerja pegawai adalah kualitas, kuantitas, tanggung jawab, kerjasama dan inisiatif.

2. Variabel Independen

Dalam penelitian ini yang menjadi variabel independen adalah:

a. Motivasi (X1)

Motivasi adalah kondisi jiwa yang mendorong seseorang dalam mencapai prestasinya secara maksimal (Mc Clelland, dalam Mangkunegara, 2009). Penelitian ini menggunakan konsep dari Mc Clelland karena berfokus pada tiga kebutuhan pegawai yang harus dipenuhi organisasi. Kebutuhan berprestasi mendorong pegawai untuk bekerja melebihi standar, kebutuhan akan kekuatan menimbulkan sikap kepemimpinan dalam diri pegawai dan kebutuhan akan hubungan mendorong pegawai untuk menjalin koneksi antar rekan kerja. Konsep Mc Clelland juga telah banyak digunakan dalam penelitian terdahulu untuk mengukur motivasi kerja pegawai khusus instansi pemerintah.

\section{b. Disiplin Kerja (X2)}

Dalam penelitian ini disiplin kerja merupakan ketaatan dan kepatuhan pegawai dalam melaksanakan tugas dan perilaku di lingkungan kerja dan kesesuaiannya dengan aturan yang telah ditentukan dan berlaku di dinas pertanian kabupaten supiori. Indikator yang digunakan dalam penelitian ini untuk mengukur disiplin kerja adalah absensi (kehadiran), bekerja sesuai prosedur dan ketaatan pada kewajiban tugas dan peraturan.

\section{Pengujian Kuesioner}

Peneliti melakukan pengujian kuesioner terlebih dahulu sebelum melakukan penelitian yang sebenarnya. Uji coba terhadap kuesioner tersebut dilakukan untuk mengetahui validitas dan reabilitas suatu kuesioner yang akan digunakan dalam penelitian. Hasil validitas dan reabilitas pada uji kuesioner tersebut adalah sebagai berikut

\section{Uji Validitas Kuesioner}

Uji validitas dilakukan untuk mengukur apakah kuesioner layak untuk dijadikan instrumen penelitian. Kuesioner yang digunakan untuk menunjukkan apakah data yang diperoleh merupakan data yang valid. Uji validitas dilaksanakan dengan rumus kolerasi bivariate dengan alat bantu Program SPSS versi 21.0 for windows. Item angket dalam $\mathrm{Uji}$ validitas dikatakan valid jika harga nilai $r$ hitung $>$ dari $r$ tabel dan nilai9 signifikasi 0.05 . sebaliknya Item di katakan tidak valid jika harga nilai $r$ hitung < dari $r$ tabel dan pada nilai signifikasi 0.05. Uji validitas ini dilakukan kepada 30 responden diluar sampel. Adapun ringkasan hasil uji validitas sebagaimana data dalam tabel berikut ini:

Tabel 5 menunjukkan bahwa seluruh butir pertanyaan valid, yang dapat dilihat dari rhitung Corrected Item-Total Correclation yang pada keseluruhan butir lebih besar dari rtabel $(0,361)$ sehingga diperoleh 28 pertanyaan valid yang digunakan untuk melakukan penelitian.

\section{Uji Reliabilitas Angket}

Uji Reliabilitas merupakan alat untuk mengukur suatu kuesioner yang merupakan indikator dari variabel atau konstruk. Suatu kuesioner dikatakan reliable atau handal jika jawaban seseorang terhadap pertanyaan konsisten atau stabil dari waktu ke waktu. Uji reliabilitas dilakukan dengan menggunakan rumus alpha. Kuesioner dinyatakan reliabel apabila alpha > rtabel (0,361). Berdasarkan Tabel 6. Pengujian pada tabel uji reliabilitas, diketahui bahwa semua variabel mempunyai nilai Cronbach's Alpha lebih besar dari 0,361. Maka dapat disimpulkan bahwa keseluruhan variabel dalam penelitian ini reliabel. 
Tabel 3. Alternatif Jawaban dengan Skala Likert

\begin{tabular}{|c|c|c|}
\hline \multirow[t]{2}{*}{ Indikator } & \multicolumn{2}{|c|}{ Bobot Nilai } \\
\hline & Bila Positif & Bila Negatif \\
\hline 1. SS (Sangat Setuju) & 5 & 1 \\
\hline 2. S (Setuju) & 4 & 2 \\
\hline 3. R (Ragu-ragu) & 3 & 3 \\
\hline 4. TS (Tidak Setuju) & 2 & 4 \\
\hline 5. STS (Sangat Tidak Setuju) & 1 & 5 \\
\hline
\end{tabular}

Sumber: Sugiyono, (2004)

Tabel 4. Konsepsi Pengukuran Variabel Penelitian

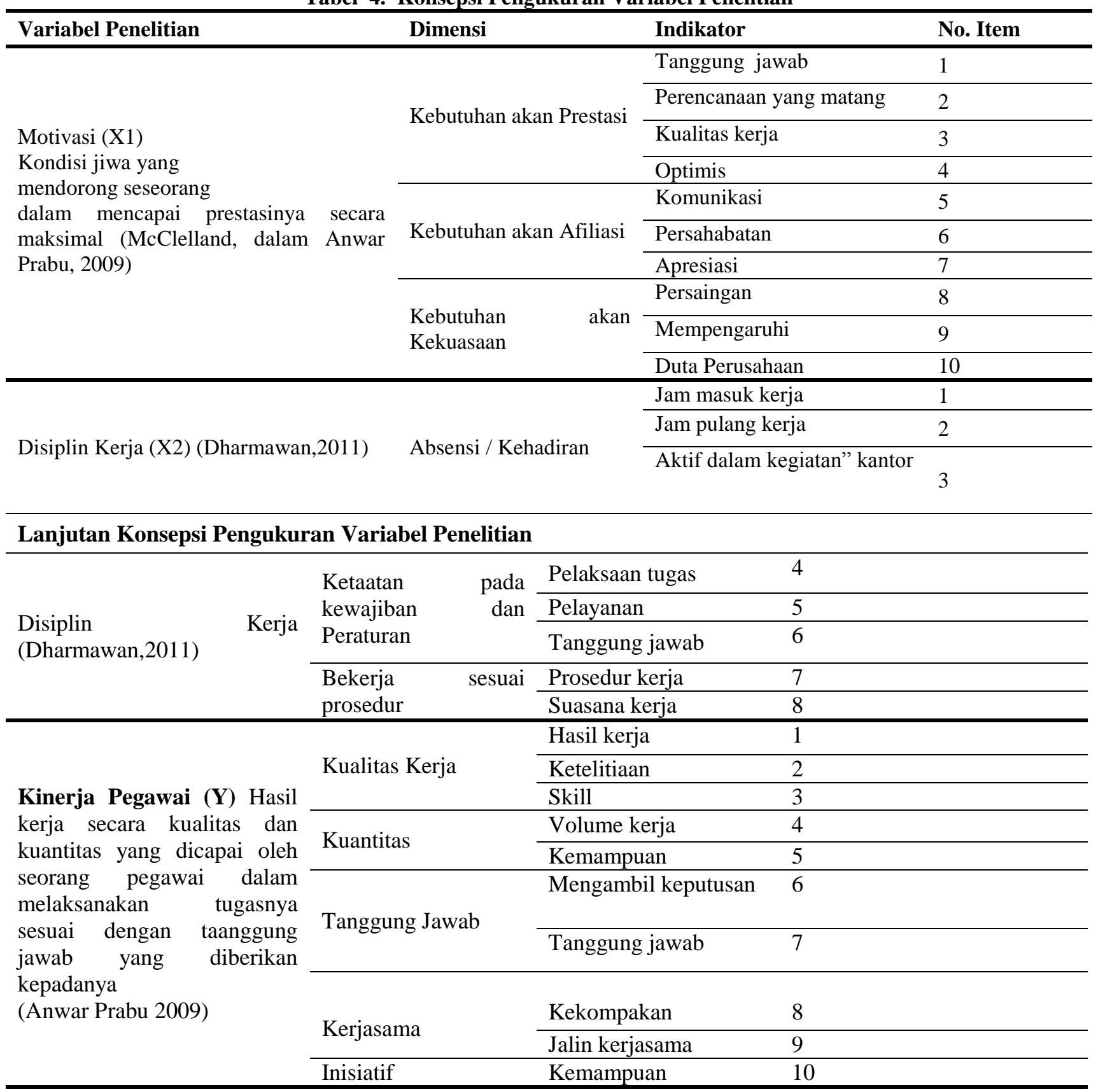


Tabel 5. Hasil pengujian Validitas

\begin{tabular}{|c|c|c|c|c|}
\hline Variabel & $\begin{array}{l}\text { Butir } \\
\text { Pertanyaan }\end{array}$ & r-hitung & r-tabel & Ket \\
\hline \multirow{10}{*}{ Motivasi (X1) } & $\mathrm{X} 1 \_1$ & 0,509 & 0,361 & Valid \\
\hline & $\mathrm{X} 1 \_2$ & 0,403 & 0,361 & Valid \\
\hline & $\mathrm{X} 1 \_3$ & 0,382 & 0,361 & Valid \\
\hline & X1_4 & 0,731 & 0,361 & Valid \\
\hline & $\mathrm{X} 1 \_5$ & 0,428 & 0,361 & Valid \\
\hline & X1_6 & 0,449 & 0,361 & Valid \\
\hline & $\mathrm{X} 1 \_7$ & 0,576 & 0,361 & Valid \\
\hline & $\mathrm{X} 1 \_8$ & 0,553 & 0,361 & Valid \\
\hline & X1_9 & 0,404 & 0,361 & Valid \\
\hline & $\mathrm{X} 1 \_10$ & 0,751 & 0,361 & Valid \\
\hline \multirow{8}{*}{ Disiplin Kerja (X2) } & $\mathrm{X} 2 \_1$ & 0,801 & 0,361 & Valid \\
\hline & $\mathrm{X} 2 \_2$ & 0,774 & 0,361 & Valid \\
\hline & $\mathrm{X} 2 \_3$ & 0,646 & 0,361 & Valid \\
\hline & $\mathrm{X} 2 \_4$ & 0,560 & 0,361 & Valid \\
\hline & $X 2 \_5$ & 0,569 & 0,361 & Valid \\
\hline & $X 2 \_6$ & 0,798 & 0,361 & Valid \\
\hline & $\mathrm{X} 2 \_7$ & 0,473 & 0,361 & Valid \\
\hline & $\mathrm{X} 2 \_8$ & 0,560 & 0,361 & Valid \\
\hline \multirow{10}{*}{ Kinerja (Y) } & Y_1 & 0,767 & 0,361 & Valid \\
\hline & Y_2 & 0,474 & 0,361 & Valid \\
\hline & Y_3 & 0,697 & 0,361 & Valid \\
\hline & Y_4 & 0,636 & 0,361 & Valid \\
\hline & Y_5 & 0,659 & 0,361 & Valid \\
\hline & Y_6 & 0,699 & 0,361 & Valid \\
\hline & Y_7 & 0,722 & 0,361 & Valid \\
\hline & Y_8 & 0,666 & 0,361 & Valid \\
\hline & Y_9 & 0,672 & 0,361 & Valid \\
\hline & Y_10 & 0,405 & 0,361 & Valid \\
\hline \multicolumn{5}{|c|}{ Tabel 6. Hasil Pengujian Reliabilitas } \\
\hline Variabel & $\begin{array}{c}\text { Cronbach's } \\
\text { Alpha }\end{array}$ & & ems & Keterangan \\
\hline Motivasi & 0,696 & & & Reliabel \\
\hline Disiplin Kerja & 0,803 & & & Reliabel \\
\hline Kinerja & 0,817 & & & Reliabel \\
\hline
\end{tabular}

\section{Teknik Analisis Data}

Setelah data terkumpul maka data tersebut harus segera dianalisa untuk mengetahui kebenaran dari hipotesis dan untuk menarik kesimpulan. Teknik analisis data yang digunakan dalam penelitian ini adalah teknik analisis deskriptif dan regresi linear berganda. Selanjutnya langkah-langkah analisis dalam penelitian ini adalah:

\section{Analisis Deskriptif}

Analisis deskriptif adalah analisis data dengan cara menggambarkan data yang telah terkumpul. Analisis deskriptif dilakukan untuk mengetahui karakteristik responden berdasarkan jenis kelamin, umur, tingkat pendidikan, masa kerja, motivasi, disiplin dan kinerja kerja dengan cara tabulasi hasil kuesioner secara manual.

\section{Analisis Regresi Linier Berganda}

Dalam penelitian ini peneliti menggunakan analisis statistik regresi linear berganda. Analisis regresi linear berganda digunakan untuk menganalisis pengaruh antara variabel independen (motivasi dan 
disiplin kerja) terhadap variabel dependen yaitu kinerja. Persamaan yang digunakan adalah:

\begin{tabular}{|c|}
\hline $\mathbf{Y}=\mathbf{a}+\mathbf{b}_{1} \mathbf{X} \mathbf{1}+\mathbf{b}_{2} \mathbf{X} \mathbf{2}+\mathbf{e}$ \\
\hline $\begin{array}{ll}\text { Keterangan }: \\
\mathrm{Y} & : \text { Kinerja } \\
\mathrm{a} & : \text { Konstanta } \\
\mathrm{X} 1 & : \text { Motivasi } \\
\mathrm{X} 2 & : \text { Disiplin kerja } \\
\mathrm{b}_{1}, \mathrm{~b}_{2}, & : \text { Koefisien regresi } \\
\mathrm{e} & : \text { error }\end{array}$ \\
\hline
\end{tabular}

\section{Uji Asumsi Klasik}

\section{Uji Normalitas}

Uji normalitas bertujuan untuk mengetahui data yang dianalisis berbentuk atau mempunyai distribusi normal atau tidak. Langkah yang dilakukan dalam uji ini adalah dengan menggunakan Normal Probability Plot. Jika distribusi data normal, maka sebaran data akan berada di sekitar garis diagonal dan mengikuti arah garis diagonal.

\section{Uji Goodness of Fit}

Uji Goodness of Fit digunakan untuk mengukur ketepatan fungsi regresi sampel dalam menaksir nilai aktual. Uji Goodness of Fit dapat dilakukan dengan metode statistik, yaitu melalui pengukuran nilai koefisien determinasi, uji $F$ (simultan) dan uji t (parsial).

\section{Koefisien Determinasi $\left(\mathbf{R}^{2}\right)$}

Koefisien determinasi $\left(\mathrm{R}^{2}\right)$ digunakan unutk mengukur seberapa jauh kemampuan model dalam menerangkan variasi variabel dependen. Nilai koefisien determinasi adalah antara nol dan satu. Nilai $\mathrm{R}^{2}$ yang kecil berarti kemampuan variabel-variabel independen dalam menjelaskan variasi variabel dependen terbatas. Nilai yang mendekati satu berarti variabel-variabel independen memberikan hampir semua informasi yang dibutuhkan untuk memprediksi variasi variabel dependen. Adapun rumus Koefisien Determinasi adalah sebagai berikut :

$$
K D=R^{2} \times 100 \%
$$

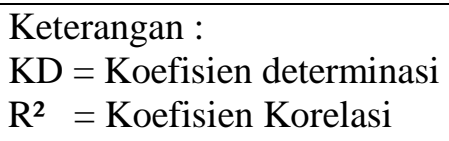

Keterangan :

$\mathrm{KD}=$ Koefisien determinasi

$\mathrm{R}^{2}=$ Koefisien Korelasi

\section{Uji Simultan (Uji F)}

Uji $F$ yaitu suatu uji untuk mengetahui pengaruh variabel tidak terikat yaitu motivasi (X1) dan disiplin kerja (X2) secara simultan terhadap variabel terikat yaitu kinerja $(\mathrm{Y})$.

a. Hipotesis untuk pengujian F-test, yaitu:

1) $\mathrm{H} 0: \mathrm{b} 1=\mathrm{b} 2=\mathrm{b} 3=0$

Artinya: tidak ada pengaruh yang signifikan dari variabel tidak terikat yaitu motivasi (X1) dan disiplin kerja (X2) secara simultan terhadap variabel terikat yaitu kinerja pegawai (Y).

2) $\mathrm{H} 1: \mathrm{b} 1-\mathrm{b} 3>0$

Artinya: ada pengaruh yang signifikan dari variabel tidak terikat yaitu kualitas motivasi (X1) dan disiplin kerja (X2) secara simultan terhadap variabel terikat yaitu kinerja $(\mathrm{Y})$.

b. Menentukan F tabel dan F hitung.

Dengan taraf signifikansi sebesar $5 \%$, maka:

1) Jika $\mathrm{F}$ hitung $>\mathrm{F}$ tabel, maka $\mathrm{H} 0$ ditolak, berarti masing-masing variabel tidak terikat secara bersama-sama mempunyai pengaruh yang signifikan terhadap variabel terikat.

2) Jika F hitung < F tabel, maka H0 diterima, berarti masing-masing variabel tidak terikat secara bersama-sama tidak mempunyai pengaruh yang signifikan terhadap variabel terikat.

\section{Uji t (Parsial)}

Pengujian ini dilakukan untuk mengetahui seberapa jauh pengaruh suatu variabel tidak terikat secara parsial (individual) terhadap variasi variabel terikat.

Hipotesis yang dipakai:

1) $\mathrm{HO}: \mathrm{bi}=0$

Artinya: variabel independen tidak berpengaruh terhadap variabel dependen.

2) $\mathrm{H} 1:$ bi $>0$

Artinya: variabel independen berpengaruh positif terhadap variabel dependen.

Kriteria pengujian dengan tingkat signifikansi

(a) $=0,05$ ditentukan sebagai berikut:

1) thitung < ttabel, maka HO diterima

2) thitung > ttabel, maka H0 ditolak 


\section{HASIL DAN PEMBAHASAN}

\section{Gambaran Umum Obyek Penelitian}

Dinas Pertanian Kabupaten Supiori adalah dinas pemerintahan yang mempunyai tugas menyelenggarakan kewenangan desentralisasi dan dekonsentrasi di bidang pertanian tingkat kabupaten. Dinas pertanian ini di bentuk berdasarkan Peraturan Daerah No.3 tahun 2008 Tentang tata kerja dinas-dinas daerah pemerintah kabupaten Supiori. Berdirinya dinas pertanian ini dimaksudkan untuk meningkatnya produksi pertanian khususnya produksi pangan lokal, perkebunan, dan peternakan yang dapat memenuhi kebutuhan bahan konsumsi pangan masyarakat sehingga tercipta kemandirian dalam pemenuhan bahan kebutuhan pangan serta gizi masyarakat di kabupaten supiori.

\section{Visi, Misi dan Tujuan Dinas Pertanian Supiori}

a) Visi Dinas Pertanian Supiori

"Mempercepat Pemberdayaan Ekonomi

Masyarakat Supiori Melalui Peningkatan dan Pemanfaatan Pertanian (Pertanian, Perkebunan dan Peternakan) Tanaman Lokal”.

b) Misi Dinas Pertanian Supiori

- Peningkatan kesejahteraan rakyat melalui peningkatan pendapatan petani.

- Mempercepat pemberdayaan ekonomi kerakyatan melalui peningkatan usaha taninya secara agribisnis.

- Peningkatan kesehatan melalui peningkatan pangan dan gizi.

c) Tujuan Dinas Pertanian Supiori

Secara garis besar tujuan Dinas Pertanian

Supiori adalah sebagai berikut :

- Terwujudnya pembangunan pertanian dan kehutanan di Kabupaten Supiori dengan memanfaatkan secara optimal potensi sumber daya lahan yang tersedia, melalui kegiatan usahatani masyarakat secara partisipatif dengan menerapkan teknologi tepat guna.

- Terciptanya sistem agribisnis yang sehat dan dinamis dalam usahatani masyarakat sehingga dapat meningkatkan produksi pertanian lokal serta pendapatan usahatani masyarakat dalam meningkatkan kesejahteraan rakyat di kabupaten supiori

- Pembangunan pertanian di Kabupaten Supiori dapat berkembang dan maju sehingga dapat memberi kontribusi yang nyata bagi pembangunan ekonomi daerah di kabupaten supiori.

- Pembangunan pertanian di Kabupaten Supiori dapat meningkat sejajar dengan daerah otonom kabupaten lainnya di Provinsi Papua serta menjadi daerah penyangga bagi Kabupaten Biak Numfor sebagai Kabupaten terdekat yang lebih padat penduduknya.

- Terlaksananya pembangunan pertanian di Kabupaten Supiori yang didukung oleh sumber daya manusia baik aparatur maupun kelembagaan petani yang kuat, maju dan bersinergi, sebagai modal penting bagi pelaksanaan pembangunan yang berkelanjutan.

\section{Hasil Penelitian}

Data yang digunakan dalam penelitian ini adalah data primer. Data primer diperoleh dengan cara menyebar kuesioner kepada pegawai dinas pertanian kabupaten supiori. Kuesioner terkait tentang variabel motivasi, disiplin kerja, dan kinerja pegawai. Sampel dalam penelitian ini berjumlah 80 responden. Jumlah sampel diambil dari populasi dikarenakan populasi $<100$. Jumlah item indikator yang ada dalam penelitian ini adalah 28 pernyataan.

\section{Karekteristik Responden}

Karakteristik responden yang dianalisis dalam penelitian ini meliputi jenis kelamin, pendidikan terakhir, masa kerja dan jabatan.

\section{1) Karakteristik Responden Berdasarkan Jenis Kelamin}

Berdasarkan hasil penelitian diperoleh karakteristik responden pegawai dinas pertanian supiori berdasarkan jenis kelamin disajikan pada tabel 7 berikut ini:

Berdasarkan tabel 7 dapat dilihat bahwa responden dengan jenis kelamin laki - laki sebanyak 41 responden $(41,2 \%)$ dan responden dengan jenis kelamin perempuan sebanyak 39 responden $(58,8 \%)$.

\section{2) Karakteristik Responden Berdasarkan Usia}

Variatifnya usia pegawai dinas pertanian supiori, maka akan memungkinkan responden juga bervariasi berdasarkan usia. Data responden berdasarkan umur dapat dilihat dalam tabel 8 berikut. Berdasarkan tabel 8 dapat dilihat bahwa sebagian besar pegawai dinas pertanian supiori berusia antara $30-40$ tahun berjumlah 41 orang 
atau $(51,2 \%)$ dari 80 responden. Pegawai yang berusia dibawa 30 tahun berjumlah 21 orang atau $(26,2 \%)$, usia di atas 40 tahun berjumah 18 orang atau $(22,5 \%)$ dari jumlah responden keseluruhan. Dari data tersebut dapat dikatakan bahwa rata rata usia pegawai dinas pertanian supiori masih tergolong pada usia produktif.

\section{3) Karakteristik Responden Berdasarkan Pendidikan}

Pola kinerja pegawai dapat dipengaruhi oleh tingkat pendidikan. Semakin tinggi pendidikan sesorang maka semakin tinggi pola berpikir yang dapat mempengaruhi kinerja pegawai tersebut. Oleh karena itu instansi harus mampu mengetahui kinerja pegawai dari tingkat pendidikan dengan cara menerapkan strategi yang tepat terutama dalam kinerja pegawai.Sehingga dalam penelitian ini deskripsi berdasarkan tingkat pendidikan merupakan hal yang penting untuk diketahui. Berikut ini adalah deskripsi berdasarkan tingkat pendidikan. Berdasarkan tabel 9 dapat dilihat bahwa tingkat pendidikan sebagian besar pegawai dinas pertanian supiori berpendidikan $\mathrm{S} 1$ sebanyak 40 orang atau $(49,9$ $\%)$ dari 80 responden pegawai, diikuti dengan pendidikan SMA sebanyak 27 orang atau (33,8\%), D3 sebanyak 7 orang atau $(8,8 \%)$, S2 sebanyak 6 orang atau $(7,5 \%)$ dari keseluruhan responden. Ini menunjukkan bahwa instansi dalam merekrut pegawai sebagai besar mempunyai pendidikan diploma dan sarjana, sehingga dengan latar belakang pendidikan ini diharapkan menjadi salah satu modal dari pegawai untuk bekerja secara optimal dalam mendukung kemajuan instansi.

\section{4) Karakteristik Responden Berdasarkan Masa Kerja}

Masa kerja mempunyai kaitan erat dengan tingkat disiplin pegawai. Sedangkan disiplin pegawai mempunyai hubungan dengan kinerja. Deskripsi responden berdasarkan masa kerja adalah sebagai berikut. Berdasarkan tabel 10 dapat dilihat bahwa masa kerja pegawai dinas pertanian supiori yang menjadi responden dalam penelitian ini adalah 42 orang atau $(52,5 \%)$ telah bekerja 5 - 10 tahun. Pegawai yang berkerja lebih dari 10 tahun sebanyak 28 orang atau $(35 \%)$ dan pegawai dengan masa kerja kurang dari 5 tahun sebanyak 10 orang atau $(12,5 \%)$ dari keseluruhan jumlah responden. Dengan pegawai yang mayoritas memiliki masa kerja yang lama diharapkan mampu bekerja yang inovatif dan kreatif, karena masa kerja yang lama pegawai umumnya lebih memahami bagaimana manajemen pola kerja yang diterapkan dalam organisasi.

\section{5) Karakteristik Responden Berdasarkan Jabatan}

Deskripsi karakteristik responden berdasarkan jabatan/pangkat dapat dilihat pada tabel 11 berikut ini. Berdasarkan tabel 11 dapat dilihat bahwa terdapat 3 responden $(3,75 \%)$ yang memiliki pangkat (jabatan) Pembina tk. 1, sebanyak 3 responden $(3,75 \%)$ yang memiliki pangkat (jabatan) pembina, sebanyak 6 responden $(7,5 \%)$ yang memiliki pangkat (jabatan) penata tk. 1 , sebanyak 8 responden $(10 \%)$ yang memiliki pangkat (jabatan) penata, sebanyak 19 responden $(23,75 \%)$ yang memiliki pangkat (jabatan) penata muda tk. 1 , sebanyak 7 responden $(8,75 \%)$ yang memiliki pangkat (jabatan) penata muda, sebanyak 9 responden $(11,25 \%)$ yang memiliki pangkat (jabatan) pengatur tk.1, sebanyak 14 responden $(17,5 \%)$ yang memiliki pangkat (jabatan) pengatur, sebanyak 7 responden $(8,75 \%)$ yang memiliki pangkat (jabatan) pengatur muda tk. 1 , sebanyak 4 responden (5\%) yang memiliki pangkat (jabatan) pengatur muda. Dapat disimpulkan bahwa mayoritas responden memiliki pangkat (jabatan) Penata muda tk I.

Tabel 7. Karakteristik Responden Berdasarkan Jenis Kelamin

\begin{tabular}{lll}
\hline Jenis Kelamin & Frekuensi & Persentase \\
\hline Laki-laki & 41 & 51,2 \\
Perempuan & 39 & 48,8 \\
\hline Total & 80 & $100 \%$ \\
\hline
\end{tabular}

Sumber: Hasil Data Primer, 2016 (Diolah) 
Tabel 8. Karakteristik Responden Berdasarkan Usia

\begin{tabular}{lll}
\hline Usia & Frekuensi & Persentase \\
\hline$<30$ tahun & 21 & 26,2 \\
$30-40$ tahun & 41 & 51,2 \\
$>40$ tahun & 18 & 22,6 \\
\hline Total & 80 & $100 \%$ \\
\hline
\end{tabular}

Sumber: Hasil Data Primer, 2016 (Diolah)

Tabel 9. Karakteristik Responden Berdasarkan Pendidikan

\begin{tabular}{lll}
\hline Tingkat Pendidikan & Frekuensi & Persentase \\
\hline SMA & 27 & 33,8 \\
D3 & 7 & 8,8 \\
S1 & 40 & 50 \\
S2 & 6 & 7,5 \\
\hline Total & 80 & $100 \%$ \\
\hline
\end{tabular}

Sumber: Hasil Data Primer, 2016 (Diolah)

Tabel 10. Karakteristik Responden Berdasarkan Masa Kerja

\begin{tabular}{lll}
\hline Masa Kerja & Frekuensi & Persentase \\
\hline$<5$ tahun & 10 & 12,5 \\
$5-10$ tahun & 42 & 52,5 \\
$>10$ tahun & 28 & 35 \\
\hline Total & 80 & $100 \%$ \\
\hline
\end{tabular}

Sumber: Hasil Data Primer, 2016 (Diolah)

Tabel 11. Karakteristik Responden Berdasarkan Jabatan

\begin{tabular}{lll}
\hline Jabatan & Frekuensi & Persentase \\
\hline Pembina Tingkat I (IV/b) & 3 & 3,75 \\
Pembina (IV/a) & 3 & 3,75 \\
Penata Tingkat I (III/d) & 6 & 7,5 \\
Penata (III/c) & 8 & 10 \\
Penata Muda Tk. I (III/b) & 19 & 23,75 \\
Penata Muda (III/a) & 7 & 8,75 \\
Pengatur Tk.I (II/d) & 9 & 11,25 \\
Pengatur (II/c) & 14 & 17,5 \\
Pengatur Muda Tk. I (II/b) & 7 & 8,75 \\
Pengatur Muda (II/a) & 4 & 5 \\
& & \\
\hline Total & 80 & $100 \%$ \\
\hline
\end{tabular}

Sumber: Hasil Data Primer, 2016 (Diolah)

\section{Analisis Indeks Jawaban Responden}

Analisis indeks jawaban responden dilakukan untuk mendapatkan gambaran

deskriptif penelitian yang dilakukan terhadap tiap indikator dari masing-masing variabel. Analisis ini berguna untuk mengetahui respon responden terhadap setiap pertanyaan atau pernyataan yang diajukan. Teknik skoring yang dilakukan dalam penelitian ini menggunakan Skala Likert dengan skor minimum 1 dan skor maksimum 5, maka perhitungan indeks jawaban responden dilakukan dengan rumus berikut:

Nilai Indeks $=((\mathrm{F} 1 \mathrm{X} 1)+(\mathrm{F} 2 \mathrm{X} 2)+(\mathrm{F} 3 \mathrm{X} 3)+$ $(\mathrm{F} 4 \mathrm{X} 4)+(\mathrm{F} 5 \mathrm{X} 5)$ 
Dimana:

F1 adalah frekuensi responden yang menjawab 1 dari skor yang digunakan dalam daftar pernyataan

F2 adalah frekuensi responden yang menjawab 2 dari skor yang digunakan dalam daftar pernyataan

F3 adalah frekuensi responden yang menjawab 3 dari skor yang digunakan dalam daftar pernyataan

F4 adalah frekuensi responden yang menjawab 4 dari skor yang digunakan dalam daftar pernyataan.

F5 adalah frekuensi responden yang menjawab 5 dari skor yang digunakan dalam daftar pernyataan.

Angka jawaban responden tidak berawal dari angka 0 , tetapi mulai dari angka 1 hingga 5, maka penghitungan nilai indeks jawaban akan berawal dari angka 10 hingga 100 . Total nilai indeks adalah 100 dengan menggunakan kriteria 3 kotak (Three-box Method), maka rentang 100 (10100) akan menghasilkan rentang sebesar 90. Selanjutnya rentang yang terjadi akan dibagi 3 dan akan menghasilkan rentang sebesar 30 yang digunakan sebagai dasar interpretasi nilai indeks. Penggunaan 3 kotak (Three-box Method) terbagi sebagai berikut ( Ferdinand, 2006):

$10,00-40,00=$ Rendah

$40,01-70,00=$ Sedang

$70,01-100=$ Tinggi

Dengan dasar ini, peneliti menentukan indeks persepsi responden terhadap variabelvariabel yang digunakan dalam penelitian ini.

\section{Indeks Tanggapan Responden Mengenai Motivasi}

Analisis indeks jawaban responden tentang variabel motivasi didasarkan pada jawaban responden atas 10 pernyataan yang meliputi 3 indikator yaitu kebutuhan akan prestasi, kebutuhan akan afiliasi, kebutuhan akan kekuasaan yang terdapat dalam kuesioner yang dibagikan kepada pegawai di dinas pertanian supiori.Variasi jawaban responden untuk variabel motivasi dapat dilihat pada tabel 12 di bawah ini. Hasil perhitungan tabel 12 menunjukkan bahwa motivasi masuk kedalam kriteria sedang, hal ini dapat dilihat dari skor rata-rata yang dihasilkan sebesar 64,72 dan berdasarkan rentang skor ratarata berada pada interval 40,01 - 70,00 yang berarti masuk dalam klasifikasi penilaian sedang. Akan tetapi jika melihat beberapa indikator motivasi di atas, maka ditemukan beberapa aspek yang sudah optimal, yaitu pegawai yang sudah bertanggung jawab penuh atas pekerjaannya (1) dan pegawai sudah berusaha untuk meningkatkan kualitas kerja yang lebih baik (3).

\section{Indeks Tanggapan Responden Mengenai Disiplin Kerja}

Analisis indeks jawaban responden tentang variabel disiplin kerja didasarkan pada jawaban responden atas 8 pernyataan yang meliputi 3 indikator yaitu absensi/ kehadiran, ketaatan pada kewajiban dan peraturan, bekerja sesuai prosedur, yang terdapat dalam kuesioner yang dibagikan kepada pegawai di dinas pertanian supiori.Berdasarkan hasil perhitungan tabel 13 menunjukkan bahwa disiplin kerja masuk kedalam kriteria sedang, hal ini dapat dilihat dari skor rata-rata yang dihasilkan sebesar 60,88 dan berdasarkan rentang skor rata-rata berada pada interval 40,01 - 70,00 yang berarti masuk dalam klasifikasi penilaian sedang. Hal ini menunjukan bahwa kedisiplinan kerja pada dinas pertanian kabupaten supiori masih perlu di tingkatkan lagi karena masih ada beberapa pegawai yang datang dan pulang kantor tidak tepat pada waktunya.

\section{Indeks Tanggapan Responden Mengenai Kinerja}

Analisis indeks jawaban responden tentang variabel kinerja pegawai didasarkan pada jawaban responden atas 10 pernyataan yang meliputi 5 indikator yaitu kualitas kerja, kuantitas kerja, tanggung jawab, kerjasama, inisiatif yang terdapat dalam kuesioner yang dibagikan kepada pegawai di dinas pertanian supiori. Variasi jawaban responden untuk variabel kinerja dapat dilihat pada tabel $14 \mathrm{di}$ bawah ini. Berdasarkan hasil perhitungan tabel 14 menunjukkan bahwa kinerja pegawai masuk kedalam kriteria sedang, hal ini dapat dilihat dari skor rata-rata yang dihasilkan sebesar 63,82 dan berdasarkan rentang skor rata-rata berada pada interval 40,01 - 70,00 yang berarti masuk dalam klasifikasi penilaian sedang. Hal ini menunjukkan bahwa kinerja pegawai pada dinas pertanian supiori masih belum maksimal dikarenakan dalam melaksanakan tugas masih ada pegawai yang sering melakukan kesalahan, tidak serius dalam bekerja sehingga hasil yang di berikan kurang memuaskan bagi instansi pemerintah. 


\begin{abstract}
Analisis Data
Analisis Regresi Linear Berganda

Analisis regresi linear berganda digunakan untuk menganalisis pengaruh antara variabel independen (motivasi dan disiplin kerja) terhadap variabel dependen yaitu kinerja. Data diolah secara statistik untuk keperluan analisis dan pengujian hipotesis dengan menggunakan alat bantu SPSS versi 21 For Windows. Adapun model persamaan yang digunakan adalah:
\end{abstract}

\begin{tabular}{|ll|}
\hline \multicolumn{1}{|c|}{$\quad \mathbf{Y}=\mathbf{a}+\mathbf{b}_{\mathbf{1}} \mathbf{X 1}+\mathbf{b}_{\mathbf{2}} \mathbf{X 2}+\mathbf{e}$} \\
Keterangan $:$ \\
$\mathrm{Y} \quad$ : Kinerja pegawai \\
$\mathrm{a}$ & : Konstanta \\
$\mathrm{X} 1$ & : Motivasi \\
$\mathrm{X} 2$ & : Disiplin kerja \\
$\mathrm{b}_{1}, \mathrm{~b}_{2}, \quad$ : Koefisien regresi \\
$\mathrm{e}$ & : error \\
\hline
\end{tabular}

Berdasarkan pengujian menggunakan SPSS versi 21 For Windows, maka hasil persamaan regresi linear berganda dapat dilihat pada tabel 15 dibawah ini: Untuk persamaan $\mathrm{Y}$ dari penelitian ini dapat dilihat dari kolom Unstandardized Coefficient $B$. hasil pengolahan data menggunakan SPSS 21 For Windows menunjukkan bahwa:

$$
Y=79,212+0,413 X_{1}+0,741 X_{2}+e
$$

Berdasarkan tabel 15 maka dapat diuraikan sebagai berikut:

1. Koefisien regresi motivasi (X1) sebesar 0,413.
Ini menunjukkan bahwa variabel ini berpengaruh secara positif dan signifikan terhadap kinerja atau dengan kata lain jika variabel X1 ditingkatkan sebesar satu satuan dengan asumsi variabel lain konstan, maka kinerja pegawai pada dinas pertanian supiori akan meningkat sebesar 0,413.

Artinya setiap ada peningkatan motivasi (X1) seperti selalu optimis dalam meraih keberhasilan, bekerja sama, berusaha untuk meningkatkan kualitas kerja dan bertanggung jawab atas pekerjaan yang diberikan maka kinerja pegawai juga akan semakin meningkat. Sebaliknya apabila ada penurunan motivasi (X1) maka kinerja pegawai dinas pertanian supiori akan semakin menurun.

2. Koefisien regresi Disiplin kerja (X2) sebesar 0, 741. Ini menunjukkan bahwa variabel ini berpengaruh secara positif dan signifikan terhadap kinerja pegawai, atau dengan kata lain jika variabel X2 ditingkatkan sebesar satu satuan dengan asumsi variabel lain konstan, maka kinerja pegawai pada dinas pertanian supiori akan meningkat sebesar 0,741

Artinya setiap ada peningkatan disiplin kerja (X2) seperti selalu datang dan pulang kantor tepat waktu, mengikuti tata tertib dan peraturan yang berlaku serta bekerja sesuai prosedur yang ditetapkan organisasi maka kinerja pegawai juga akan semakin meningkat. Sebaliknya apabila ada penurunan disiplin kerja (X2) maka kinerja pegawai dinas pertanian supiori akan semakin menurun.

Tabel 12. Hasil Tanggapan Responden Terhadap Variabel Motivasi (X1)

\begin{tabular}{ccccccccc}
\hline & \multicolumn{9}{c}{ Kategori } & & & & Nilai & \\
\cline { 2 - 5 } No.item & SS & S & KS & TS & STS & Total & Indeks & Kriteria \\
\hline & & & & & & & & Tinggi \\
1 & 35 & 43 & 1 & 1 & 0 & 80 & 70,4 & Sedang \\
2 & 31 & 44 & 5 & 0 & 0 & 80 & 69,2 & Tinggi \\
3 & 35 & 44 & 1 & 0 & 0 & 80 & 70,8 & Sedang \\
4 & 26 & 46 & 8 & 0 & 0 & 80 & 67,6 & Sedang \\
5 & 22 & 38 & 15 & 5 & 0 & 80 & 63,4 & Sedang \\
6 & 26 & 49 & 5 & 0 & 0 & 80 & 68,2 & Sedang \\
7 & 20 & 51 & 7 & 2 & 0 & 80 & 63,6 & Sedang \\
8 & 9 & 57 & 12 & 2 & 0 & 80 & 62,6 & Sedang \\
9 & 7 & 36 & 23 & 13 & 1 & 80 & 55 & Sedang \\
10 & 8 & 32 & 34 & 6 & 0 & 80 & 56,4 & \\
\hline Jumlah & 218 & 440 & 111 & 30 & 1 & 800 & $\mathbf{6 4 , 7 2}$ & Sedang \\
\hline
\end{tabular}

Sumber: Hasil Pengolahaan, 2016 (Diolah) 
Tabel 13. Hasil Tanggapan Responden Terhadap Variabel Disiplin kerja (X2)

\begin{tabular}{lllllllll}
\hline Kategori & & & & & & & Nilai & \multirow{2}{*}{ Kriteria } \\
\cline { 2 - 6 } No.item & SS & S & KS & TS & STS & Total & Indeks & Kring \\
\hline 1 & 4 & 27 & 26 & 23 & 0 & 80 & 50,4 & Sedang \\
2 & 4 & 32 & 30 & 14 & 0 & 80 & 53,2 & Sedang \\
3 & 8 & 52 & 20 & 0 & 0 & 80 & 61,6 & Sedang \\
4 & 17 & 56 & 7 & 0 & 0 & 80 & 66 & Sedang \\
5 & 15 & 51 & 14 & 0 & 0 & 80 & 64,2 & Sedang \\
6 & 13 & 53 & 14 & 0 & 0 & 80 & 63,8 & Sedang \\
7 & 12 & 51 & 15 & 2 & 0 & 80 & 62,6 & Sedang \\
8 & 14 & 58 & 8 & 0 & 0 & 80 & 65,2 & Sedang \\
\hline Jumlah & 89 & 378 & 134 & 39 & 0 & 640 & $\mathbf{6 0 , 8 8}$ & Sedang \\
\hline
\end{tabular}

Sumber: Hasil Pengolahaan, 2016 (Diolah)

Tabel 14. Hasil Tanggapan Responden Terhadap Variabel Kinerja Pegawai (Y)

\begin{tabular}{|c|c|c|c|c|c|c|c|c|}
\hline \multirow{2}{*}{$\begin{array}{l}\text { Kategori } \\
\text { No.item }\end{array}$} & \multirow[b]{2}{*}{ SS } & \multirow[b]{2}{*}{$\mathrm{S}$} & \multirow[b]{2}{*}{$\mathrm{KS}$} & \multirow[b]{2}{*}{ TS } & \multirow[b]{2}{*}{ STS } & \multirow[b]{2}{*}{ Total } & \multirow[t]{2}{*}{ Nilai Indeks } & \multirow[t]{2}{*}{ Kriteria } \\
\hline & & & & & & & & \\
\hline 1 & 23 & 29 & 20 & 4 & 4 & 80 & 60,6 & Sedang \\
\hline 2 & 6 & 26 & 24 & 19 & 5 & 80 & 49,8 & Sedang \\
\hline 3 & 19 & 49 & 9 & 1 & 2 & 80 & 64,4 & Sedang \\
\hline 4 & 17 & 44 & 15 & 4 & 0 & 80 & 62,8 & Sedang \\
\hline 5 & 24 & 40 & 16 & 0 & 0 & 80 & 65,6 & Sedang \\
\hline 6 & 29 & 45 & 6 & 0 & 0 & 80 & 68,6 & Sedang \\
\hline 7 & 28 & 47 & 5 & 0 & 0 & 80 & 68,6 & Sedang \\
\hline 8 & 29 & 42 & 9 & 0 & 0 & 80 & 68 & Sedang \\
\hline 9 & 32 & 43 & 5 & 0 & 0 & 80 & 69,4 & Sedang \\
\hline 10 & 11 & 42 & 25 & 2 & 0 & 80 & 60,4 & Sedang \\
\hline Jumlah & 218 & 406 & 134 & 31 & 11 & 800 & 63,82 & Sedang \\
\hline
\end{tabular}

Sumber: Hasil Pengolahaan, 2016 (Diolah)

Coefficients $^{\mathrm{a}} \quad$ Tabel 15. Analisis Regresi Linear Berganda

\begin{tabular}{|c|c|c|c|c|c|c|}
\hline \multirow{2}{*}{\multicolumn{2}{|c|}{ Model }} & \multicolumn{2}{|c|}{ Unstandardized Coefficients } & \multirow{2}{*}{$\begin{array}{l}\text { Standardized } \\
\text { Coefficients } \\
\text { Beta }\end{array}$} & \multirow[b]{2}{*}{$\mathrm{T}$} & \multirow[b]{2}{*}{ Sig. } \\
\hline & & $\mathrm{B}$ & Std. Error & & & \\
\hline \multirow[t]{3}{*}{1} & (Constant) & 79.212 & 6.507 & & 12.173 & .000 \\
\hline & Motivasi_x1 & .413 & .124 & .306 & 3.318 & .001 \\
\hline & Disiplin_x2 & .741 & .140 & .489 & 5.292 & .000 \\
\hline
\end{tabular}

a. Dependent Variable: Kinerja_Y

Sumber: Hasil Pengolahaan SPSS, 2016 (Diolah)

\section{Uji Asumsi Klasik}

\section{Uji Normalitas}

Uji normalitas bertujuan untuk mengetahui data yang dianalisis berbentuk atau mempunyai distribusi normal atau tidak. Langkah yang dilakukan dalam uji ini adalah dengan menggunakan Normal Probability Plot. Jika distribusi data normal, maka sebaran data akan berada di sekitar garis diagonal dan mengikuti arah garis diagonal.

Gambar 2. P-P Plot Uji Normalitas 


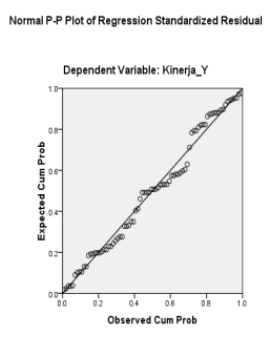

Sumber: Hasil Pengolahan SPSS, (2016)

Pada p-p plot terlihat bahwa titik-titik menyebar disekitar garis diagonal dan cenderung mengikuti arah garis diagonal. Dengan demikian maka model regresi tersebut memenuhi asumsi normalitas untuk penelitian ini.

\section{Uji Goodness of Fit}

\section{Koefisien Determinasi $\left(\mathbf{R}^{2}\right)$}

Besarnya kontribusi variabel independen mempengaruhi variabel dependen dapat diketahui dari nilai koefisien determinasi. Nilai koefisien determinasi atau $\mathrm{R}^{2}$ dapat dilihat pada hasil pengolahan data menggunakan SPSS 21 for windows pada tabel Model Summary kolom $R$ Square sebagai berikut:

Dari tabel 16 terlihat bahwa angka $\mathrm{R}$ yang dihasilkan sebesar 0,586. Hal ini menunjukkan bahwa korelasi atau hubungan antara kinerja (variabel dependent) dengan nilai variabelvariabel independennya (variabel motivasi dan disiplin kerja) adalah sedang. Angka koefisien determinasi atau $\mathrm{R}^{2}$ yang dihasilkan adalah sebesar $0,344 \%$. Nilai adjusted $\mathrm{R}$ square yaitu sebesar $0,327 \%$,. Hal ini berarti $34,4 \%$ variasi dari kinerja bisa dijelaskan oleh kedua variabel independent yang digunakan dalam persamaan regresi. Sedangkan selebihnya yaitu $65,6 \%(100 \%$ - 34,4\%) dapat dijelaskan atau diprediksi oleh variabel lain di luar kedua variabel yang digunakan dalam penelitian ini.

\section{Simultan (Uji-F)}

Pengujian ini dilakukan untuk melihat secara bersama-sama pengaruh atau hubungan positif signifikan variabel tidak terikat yaitu motivasi (X1) dan disiplin kerja (X2) terhadap variabel terikat yaitu kinerja $(\mathrm{Y})$.

Berdasarkan tabel 17 menunjukkan bahwa nilai Fhitung (20.179) > Ftabel dengan tingkat signifikansi $0,000<0,05$. Hal ini menunjukkan bahwa variabel tidak terikat yaitu motivasi (X1) dan disiplin kerja (X2) secara bersama-sama berpengaruh dan signifikan terhadap variabel terikat yaitu kinerja (Y) pegawai di dinas pertanian supiori. Hasil penelitian ini menunjukkan bahwa motivasi dan disiplin kerja secara bersama-sama (simultan) mempengaruhi kinerja pegawai dinas pertanian supiori dimana dapat diketahui dari nilai koefisien regresi masing-masing variabel bebas memiliki tanda positif, hasil uji hipotesis dari uji $\mathrm{F}$ menunjukkan Fhitung sebesar 20.179 dengan taraf signifikansi 0,000 yang lebih kecil dari 0,005. Hal ini menunjukkan hubungan yang searah antara variabel motivasi (X1) dan disiplin kerja (X2) dengan kinerja pegawai $(\mathrm{Y})$. Hal ini diperkuat dari hasil penelitian terdahulu oleh Harlie, M. (2012). Pengaruh Disiplin Kerja, Motivasi dan Pengembangan Karier terhadap Kinerja PNS pada PemKab Tabalong di Tanjung Kalimantan Selatan.

\section{Uji Parsial (Uji-t)}

Uji t dilakukan untuk mengetahui apakah variabel tidak terikat terdiri dari variabel motivasi (X1) dan disiplin kerja (X2) secara parsial atau individu mempunyai pengaruh terhadap variabel terikat yaitu kinerja (Y).

Berdasarkan tabel 18 Uji Parsial terlihat bahwa:

a) Variabel motivasi dengan t hitung $>$ dari t tabel atau 3,318>1,990, maka $\mathrm{H}_{0}$ di tolak dan $\mathrm{H}_{1}$ di terima (hipotesis penelitian), artinya motivasi mempunyai pengaruh yang signifikan terhadap kinerja. Hasil pengujian menunjukkan bahwa variabel motivasi (X1) memiliki thitung 3.318 dengan tingkat signifikansi 0,001 . Oleh karena probabilitas $(0,001)$ lebih kecil dari 0,05 maka koefisien regresi dari motivasi (X1) berpengaruh secara signifikan terhadap kinerja pegawai (Y) di Dinas Pertanian Kabupaten Supiori.

Variabel motivasi merupakan variabel yang mempunyai pengaruh terhadap kinerja pegawai, hal ini dapat dilihat secara langsung adanya dorongan dalam diri pegawai untuk selalu berusaha meningkatkan kualitas kerja yang lebih baik,bertanggung jawab serta selalu optimis untuk dapat meraih keberhasilan, sehingga secara otomatis menyebabkan meningkatnya kinerja pegawai dalam lingkungan kerja di Dinas Pertanian Kabupaten Supiori.

b) Variabel disiplin kerja dengan $\mathrm{t}$ hitung $>$ dari $\mathrm{t}$ tabel atau 5,292 > 1,990 maka $\mathrm{H}_{0}$ ditolak dan $\mathrm{H}_{1}$ diterima (hipotesis penelitian), artinya 
disiplin kerja mempunyai pengaruh yang signifikan terhadap Kinerja. Hasil pengujian menunjukkan bahwa variabel disiplin kerja (X2) memiliki thitung 5.292 dengan tingkat signifikansi 0,000 . Oleh karena signifikansi $(0,000)$ lebih kecil dari 0,05 maka koefisien regresi dari disiplin kerja (X2) berpengaruh secara signifikan terhadap kinerja pegawai (Y) di Dinas Pertanian Kabupaten Supiori.

Berdasarkan hasil pengujian uji t disiplin kerja memberikan kontribusi yang besar dengan tingkat signifikansi 0,000 lebih kecil dari 0,05 berbanding dengan motivasi yang tingkat signifikansi 0,001 lebih kecil dari 0,05 maka bisa dikatakan disiplin kerja yang dilakukan oleh pegawai dinas pertanian telah sesuai dengan tatatertib dan peraturan yang berlaku di lingkungan Dinas Pertanian Kabupaten Supiori. Dari kedua variabel independent yang diuji secara individual yang paling dominan dalam mempengaruhi kinerja pegawai di Dinas Pertanian Kabupaten Supiori adalah disiplin kerja (dengan koefisien 0,489), Hal ini menunjukkan displin kerja merupakan variabel yang paling penting dalam menentukan kinerja pegawai dalam organisasi. Variabel berikutnya yang memiliki peran yang cukup besar dalam mempengaruh kinerja pegawai di Dinas Pertanian Kabupaten Supiori adalah motivasi (dengan koefisien 0,306). Semua variabel independent dalam penelitian ini berpengaruh positif terhadap kinerja pegawai di Dinas Pertanian Kabupaten Supiori.

Model Summary

Tabel 16. Koefisien Determinasi

Std. Error of the

Model

R Square

Adjusted R Square Estimate

\begin{tabular}{lllll}
\hline 1 & $.586^{\mathrm{a}}$ & .344 & .327 & 4.268 \\
\hline
\end{tabular}

a. Predictors: (Constant), Disiplin_x2, Motivasi_x1

Sumber : Hasil Pengolahaan SPSS, 2016 (data diolah)

ANOVA $^{b}$

Tabel 17. Uji Simultan (Uji-F)

\begin{tabular}{lllllll}
\hline Model & & Sum of Squares & Df & Mean Square & F & Sig. \\
\hline 1 & Regression & 735.229 & 2 & 367.615 & 20.179 & $.000^{\mathrm{a}}$ \\
& Residual & 1402.758 & 77 & 18.218 & & \\
& Total & 2137.988 & 79 & & & \\
\hline
\end{tabular}

a. Predictors: (Constant), Disiplin_x2, Motivasi_x1

b. Dependent Variable: Kinerja_Y

Sumber: Hasil Pengolahaan, 2016 (data diolah)

Coefficients $^{\mathrm{a}}$

Tabel 18. Uji Parsial (Uji-t)

\begin{tabular}{|c|c|c|c|c|c|c|}
\hline \multirow[b]{2}{*}{ Model } & & \multicolumn{2}{|c|}{ Unstandardized Coefficients } & \multirow{2}{*}{$\begin{array}{l}\text { Standardized } \\
\text { Coefficients } \\
\text { Beta }\end{array}$} & \multirow[b]{2}{*}{$\mathrm{T}$} & \multirow[b]{2}{*}{ Sig. } \\
\hline & & $\mathrm{B}$ & Std. Error & & & \\
\hline \multirow[t]{3}{*}{1} & (Constant) & 79.212 & 6.507 & & 12.173 & .000 \\
\hline & Motivasi_x1 & .413 & .124 & .306 & 3.318 & .001 \\
\hline & Disiplin_x2 & .741 & .140 & .489 & 5.292 & .000 \\
\hline
\end{tabular}

a. Dependent Variable: Kinerja_Y 


\section{KESIMPULAN DAN SARAN}

\section{Kesimpulan}

Berdasarkan hasil penelitian yang peneliti telah lakukan pada Dinas Pertanian Kabupaten Supiori, maka dapat disimpulkan sebagai berikut:

1) Variabel tidak terikat motivasi secara parsial atau terpisah berpengaruh signifikan terhadap kinerja pegawai pada Dinas Pertanian Supiori, hal ini berarti motivasi merupakan salah satu faktor yang menentukan kinerja pegawai pada Dinas Pertanian Supiori, hal ini dapat terjadi karena adanya dorongan dalam diri pegawai untuk mau meningkatkan kualitas kerja, bertanggung jawab serta selalu optimis untuk meraih keberhasilan sehingga semakin tinggi motivasi yang ada dalam diri pegawai akan mempengaruhi tingkat kinerja yang dihasilkan oleh pegawai di lingkungan Dinas Pertanian Kabupaten Supiori.

2) Variabel tidak terikat disiplin kerja secara parsial atau terpisah berpengaruh signifikan terhadap kinerja pegawai pada Dinas Pertanian Supiori, dan berdasarkan hasil uji kedua variabel independent yang diuji secara individual yang paling dominan dalam mempengaruhi kinerja pegawai di Dinas Pertanian Kabupaten Supiori adalah disiplin kerja (dengan koefisien 0,489) hal ini berarti disiplin merupakan salah satu faktor yang menentukan kinerja pegawai pada Dinas Pertanian Supiori. Jadi, jika Pegawai Dinas Pertanian Supiori disiplin dalam bekerja maka kinerja pegawai juga akan tercapai dan mengalami peningkatan.

\section{Saran}

Berdasarkan hasil penelitian yang dilakukan terhadap kinerja pegawai di Dinas Pertanian Supiori melalui variabel motivasi dan disiplin kerja, maka ada beberapa saran yang diajukan oleh peneliti kepada Dinas Pertanian Supiori. Tentu saja saran yang diajukan perlu mendapat kajian dari Dinas Pertanian Supiori agar dapat menjadi hal yang positif dalam membangun Dinas Pertanian Supiori. Berikut ini adalah beberapa saran yang diberikan oleh peneliti kepada Dinas Pertanian Supiori.

1. Bagi Dinas Pertanian Kabupaten Supiori diharapkan penelitian ini dapat dijadikan bahan masukan untuk tetap mempertahankan dan meningkatkan motivasi dan disiplin kerja di Dinas Pertanian Supiori, agar kinerja pegawai di Dinas Pertanian Supiori dapat terus meningkat

2. Bagi pimpinan instansi harus lebih menekankan disiplin yang tegas bagi para pegawai agar pegawai lebih beratnggung jawab secara penuh terhadap pekerjaan yang mereka kerjakan sehingga tercipta kedisplinan yang baik dalam lingkungan instansi.

3. Nilai $\mathrm{R}^{2}$ dalam penelitian ini sedang sehingga masih banyak faktor lain yang mempengaruhi, maka untuk riset yang akan datang agar memasukan atau menambah variable lain seperti gaya kepemimpinan, insentif, lingkungan kerja, beban kerja, R \& $\mathrm{D}$ dan sebagainya. Bagi kalangan akademisi diharapkan penelitian ini dapat dijadikan referensi untuk penelitian-penelitian yang terkait dengan kinerja pegawai sehingga peneliti dapat dengan mudah memahami variable-variabel manakah yang berpengaruh terhadap variabel kinerja pegawai.

\section{DAFTAR PUSTAKA}

Arikunto, Suharsimi. 2010. Manajemen Penelitian. Rineka Cipta. Jakarta

Aritonang, Keke T. 2005. Kompensasi Kerja, Disiplin Kerja Guru dan Kinerja Guru SMP Kristen BPK Penabur Jakarta. Jurnal Pendidikan Penabur Diakses 06-09-2016

Ahmad. 2012. Pengaruh Motivasi dan Beban Kerja Terhadap Kinerja Karyawan di Rumah Sakit Nur Hidayah Bantul. Program Pascasarjana, Universitas Indonesia. Diakses 12-09-2016

Dharmawan, I Made Yusa. 2011. Pengaruh Kompensasi dan Lingkungan Kerja Non Fisik terhadap Disiplin Kerja dan Kinerja Karyawan Hotel Nikki Denpasar. Program Studi Magister Manajemen Program Pasca Sarjana Universitas Udayana. Diakses tanggal 10-09-2016

Flippo. 2003. Manajemen Personalia, Edisi. 6, oleh Moh. Masud, SH, MA, Erlangga. Jakarta. 
Gomez, Faustino Cardodo. 2003. Manajemen Sumber Daya Manusia. Andi Offset,Yogyakarta.

Gusti Ayu Riska Riyanti dan I Gde Adnyana Sudibya. 2011. Pengaruh Motivasi dan Kompetensi Terhadap Kinerja Karyawan Pada RSU Dharma Usadha. Gaster Vol. 10 No. 1. Diakses 16-092016

Galih A, Nimpuno. 2015. Pengaruh Disiplin Kerja dan Gaya Kepemimpinan Terhadap Kinerja Karyawan UD.Pustaka Pelajar Yogyakarta. Skripsi Program Studi Manajemen Universitas Negeri Yogyakarta. Diakses 22-09-2016

Handoko, T. 2002. Manajemen Personalia \& Sumberdaya Manusia, BPFE UGM Yogyakarta.

Harlie, M. 2012. Pengaruh Disiplin Kerja, Motivasi dan Pengembangan Karier terhadap Kinerja PNS pada PemKab Tabalong di Tanjung Kalimantan Selatan. Jurnal Aplikasi Manajemen Vol. 10, No. 4, Desember 2012. Diakses tanggal 16-10-2016

Hariandja, T. Efendi. 2002. Manajemen Sumberdaya Manusia. Penerbit Gramedia. Jakarta.

Hasibuan,S.P. 2006. Manajemen Sumber Daya Manusia, Edisi Revisi PT Bumi Aksara. Jakarta.

Hakim, Abdul. 2006. Analisis Pengaruh Motivasi, Komitmen Organisasi Dan Iklim Organisasi Terhadap KinerjaPegawai Pada Dinas Perhubungan dan Telekomunikasi

Provinsi Jawa Tengah. JRBI. Vol 2. No 2. Diakses tanggal 24-09-2016

Keputusan Menteri Negara Pendayagunaan Aparatur Negara (Meneg PAN) Nomor 63/KEP/M.PAN/7/2003.

Mudiartha Utama, Wayan. 2001. Manajemen Sumber Daya Manusia.: UPT
Penerbit Universitas Udayana Denpasar

Mangkunegara, A. A, Prabu. 2009. Evaluasi Kinerja Sumber Daya Manusia.: Refika Aditama. Bandung

2011. Manajemen Sumber Daya Manusia Perusahaan. Remaja Rosdakarya. Bandung

Mulyanto, dkk. 2009. Pengaruh Motivasi, Kepuasan Kerja dan komitmen Organisasi Terhadap Kinerja Pegawai Pada Dinas Tenaga Kerja dan Transmigrasi Provinsi Daerah Istimewa Yogjakarta. Vol 1, No 2.

Manullang, M. 2004. Manajemen Personalia.: Ghalia Indonesia,Jakarta.

Narmodo, dkk. 2011. Pengaruh Motivasi dan Disiplin Terhadap Pegawai Badan Kepegawaian Daerah Kabupaten Wonogiri. Jurnal Sumber daya Manusia, Vol 1, No 2.

Notoatmodjo, S. 1998 . Pengembangan Sumber Daya Manusia (Edisi Revisi).: PT Rineka Cipta. Jakarta.

Parlinda, dkk. 2008. Pengaruh Kepemimpinan, Pelatihan dan Lingkungan Kerja Terhadap Kinerja Karyawan. Tesis, Studi Pada Karyawan Perusahaan Daerah Air Minum Surakarta. Diakses tanggal 20-08-201 Peraturan Kepala Badan Kepegawaian Negara Nomor 1 Tahun 2013 tentang Ketentuan Pelaksanaan Peraturan Pemerintah Nomor 46 Tahun 2011 Tentang Penilaian Prestasi Kerja Pegawai Negeri Sipil.

Peraturan Pemerintah Republik Indonesia Nomor 46 Tahun 2011 tentang Penilaian Prestasi Kerja Pegawai Negeri Sipil

Peraturan Daerah No. 3 tahun 2008 Tentang tata kerja dinas-dinas daerah Pemerintah Kabupaten Supiori 
Santoso Singgih. 2005 Statistik Parametik dengan SPSS. PT. Elex Media Komputindo. Jakarta

Sugiyono. 2004. Metode Penelitian Kuantitatif, Kualitatif dan R \& D, Alfabeta. Bandung.

Siti M, Laili. 2014. Pengaruh Motivasi Disiplin Kerja terhadap Kinerja Pegawai Negeri Sipil Pemerintah Kabupaten Situbondo. Skripsi : Fakultas Ekonomi Universitas Jember. Diakses 20-09-2016

Sutrisno, Edy. 2010. Manajemen Sumber Daya Manusia. Cetakan Ketiga. Kencana Prenada Media Group. Jakarta

Setiawan, dkk. 2006. Pengaruh Disiplin Kerja Karyawan dan Budaya Organisasi terhadap Kinerja di Divisi Radiologi RSUP dr. Kariadi Semarang. JRBI. Vol 2. No 2. Hal: 181-198. Diakses 20-09-2016
Sedarmayanti. 2004. Good Governance (Kepemerintahan Yang Baik), Bagian Kedua. : Mandar Maju. Bandung.

Sudjana. 2001. Metode Statistika . Penerbit Tarsito, Bandung

Timpe, Dale. 2004. Kinerja (alih bahasa Sofyan). PT.Gramedia Asri, Jakarta.

Wulan, Lucky. 2006. Analisis Pengaruh Motivasi Kerja dan Lingkungan Kerja Terhadap Kinerja Karyawan. Studi Pada DISPERINDAG, Tesis, Semarang.http://eprints.undip.ac.id/26 826/. Diakses 05-03-2016

Wexley dan Yukl. 2005. Perilaku Organisasi Dan Psikologi Perusahaan, AlihBahasa: M. Shobarudin: Rineka Cipta. Jakarta

Wahyudi dan Akdon. 2006. Manajemen Konflik dalam Organisasi, Alfabeta. Bandung. 